\title{
CONSIDERATIONS ON INTELLECTUAL LEADERSHIP IN HIGHER EDUCATION: CONCEPT ANALYSIS
}

\author{
Agnẻ Sūnelaitytè \\ Vilma Žydžiūnaitè \\ Vytautas Magnus University, Kaunas, Lithuania
}

\begin{abstract}
In the article here will be discussed the concept of intellectual leadership and the role of academic personell as intelectual leaders. The core issue in this concept analysis is the fact that many researchers choose intellectuals as the subject for their researches, and many choose leadership, but only few tried to meaningfully relate these two terms. Leadership in university is widely analysed by scholars, who tried to substantiate leadership in university with managerial and entrepreneurial theories. Increasingly growing research in the field of leadership and management in educational institutions is often focused on formal roles of University's chancellors, vice-chancellors, deans and other managers and more on intellectual capital and property development. Yet there is still lack of theoretical and empirical research concerning the intellectual leadership, and academic personell as intellectual leaders' role in university. Here universities have to re-consider the development of culture, traditions, and the environment, which would be advantageous to individuals who seeks to foster their creativeness and knowledge.
\end{abstract}

\section{Introduction}

The concept "intellectual leadership" sounds properly, but some might see an ambiguity and oxymoron in this term. It is consider that to be an intellectual and to be a leader is completely different - the intellectuals can't be good leaders, and good leaders are not necessarily intellectuals (Mcfarlane, 2012). Intellectuals are usually not attributed with strong interpersonal skills, a sense of collective responsibility, or readiness to share power or authority. This is partly due to the fact that intellectuals often believe that they are always right and do not take into account the opinions of others. Intellectuals may not even want to have followers, they often want to avoid any form of leadership and retain outside of organization (Said, 1994).

Meanwhile, the leadership is focused on charisma, inspirational motivation, intellectual promotion, individual attention and motivational factors. Such a leader has the ability to influence others and to initiate changes in their professional environment (Aarons, 2006). Still there have been no comprehensive studies of intellectual leadership, and in particular of its significance in higher education. According to Burns, (1978) intellectual leadership is one of the types of transformational leaders, and include intellectual stimulation as one of the key features of a leader. However, the concept is gaining individual value and researchers are dissociating it from transformational leadership. Here, the concept analysis is necessary to clarify a use of intellectual leadership concept in higher education, to distinguish between the defining attributes of a concept and its irrelevant use.. 
The methodology is based on the Walker and Avant (2005) method on concept analysis, which covers four steps such as (i) identification of all uses of the concept, (ii) determination of the defining attributes of the concept, (iii) identification of antecendents and consequences of the concept use and (iv) formulating the outcomes of the concept use.

\section{Uses of concept}

Due to the fact that so far there is only few researches made on the intellectual leadership as a concept and phenomenon, to find the definition of intellectual leadership in a dictionary is quite complicated. Chambers online dictionary describes intellectual as someone who has a highly developed intellect and great mental ability, while the WordWeb dictionary defines it as a person who uses mind creatively. The same dictionaries describes leader as someone who organizes or is in charge of a group, who rules, guides or inspires others.

A review of the literature in order to discover the definitions of intellectual and a leadership revealed that there are many studies that defines these two terms in various contexts. Bass \& Bass (2009) defines leadership in terms of activities and behaviors, where a leader directs group activities to a common goal. Here the leadership effectiveness can be understood as the ability to persuade followers, to inspire and influence other people to do what is necessary, although there are almost as many different definitions of leadership as there are people who have tried to define it (Northouse, 2004).

While these two concepts have been extensively studied, there is still much to discover regarding use of intellectual leadership in education field. Intellectuality in the education field can be considered in the light of Bourdieu's intellectual capital theory. Intellectual capital refers to the ability to influence public opinion and it is likely to be a product of scientific capital (Mendoza, Kuntz, Berger, 2012). According to Bourdieu's intellectual personality is twodimensional - first he must belong to a certain independent intellectual activity field and also use their power and authority to expertise and practices outside of their intellectual activity field.

Macfarlane $(2012,2011)$ as a leading researcher highlights a contrast between a leader and an intelectual within the phenomenon of 'intellectual leadership' in higher education. This idea is connected to the way in which leaders are expected to commit on collective goals and possess strong social skills, while the intellectuals are not often associated with strong interpersonal skills, a sense of communal responsibility or a preparedness to share power or authority (Macfarlane, 2012).

Summarizing the uses of concepts such as 'leadership' and 'intellectual' reveals that these two concepts have not yet been meaningfully related to one another. As leadership is usually related with inspiration, influence and persuasion of other people, whereas intellectuals implement their competencies to improve specific area of their discipline and to be an expert outside their field. In this 
case, leadership is directed to persuasion of followers in achieving goals, where intellectuals implement their expertise skills and competencies individually.

\section{Synthesis of literature Intelectuality and leadership}

Concept of 'intellectual leadership' is rarely met in the literature, and these two terms are analysed largely separately. 'Intellect' and 'leadership' are relevant in educational field as well as in other different areas - business organizations, law, politics, market, industry etc. Intellectual potential is also taken into serious consideration in these areas in terms of human resources and intellectual capital as a competitive advantage, knowledge workers as leadership imperative, companies' development and more.

Intellectual leadership in corporate value is identified as indicator which is in the medium or linkage between two subsidiary management indices - the Intellectual Equity Index and Intellectual Capital Index. It indicates the present level of managerial capability in the business entity to achieve purposeful and organizational development in relation to all its stakeholders (Dealtry, 2001). Bennis (1999) explains a leadership advantage with reference to framework for leading knowledge workers. Technical competence, conceptual skill, people skills, taste, judgement and character are considered as seven attributes essential to leadership in organization.

Competetiveness in Western firms, market development, process of leverage and governance in organizations are also based on core competencies. Those who dominate in industry are considered to be providing intellectual leadership - in terms of use of new technology, new features, new standards of quality, customer orientation and service and price-performance (Prahalad, 1993). Barling et al. (2000) relate leadership with emotional intelligence, and associate it with three aspects of transformational leadership - idealized influence, inspirational motivation and individualized consideration. According to Bollen et al. (2005), intellectual capital is an important source of an organization's economic wealth and has to be taken into serious consideration when formulating the firm's strategy. Intellectual capital importance to organizations' strategy is highlighted in research of Roos et al. (2001) where they identify it as a strategic tool in organizational management, human capital growth and commitment to organization.

Leadership role in the educational environment has gained attention as a subject for study over the past years. Leadership is taken into account in several areas succesfull special education (Smith et al. 2010), enhancement of the quality of teaching and student performance (Marks \& Printy, 2003), coupling technical and conceptual skills in distance education (Shaw, 2012), academic and administrative staff leadership in higher education (Drew, 2010; Freeman \& Kochan, 2013) and many others. Intellectual potential is also a concurrent part 
of higher education as universities are still required to maintain their role as the builders of states intellectual capital (Graham, 2005; Bousquet \& Nelson, 2008; Wepner, 2008; Mendoza et al., 2012).

Table 1

General Components of intellectual leadership in research resources

\begin{tabular}{|c|c|c|c|c|c|c|c|c|c|}
\hline Relevance & $\begin{array}{c}\text { Dealt-ry } \\
(2001)\end{array}$ & $\begin{array}{l}\text { Bennis } \\
(1999)\end{array}$ & $\begin{array}{l}\text { Praha- } \\
\text { lad } \\
(1993)\end{array}$ & $\begin{array}{c}\text { Barling } \\
\text { Slater \& } \\
\text { Kello- } \\
\text { way } \\
(2000)\end{array}$ & $\begin{array}{c}\text { Bollenet } \\
\text { al. } \\
(2005)\end{array}$ & $\begin{array}{l}\text { Roos } \\
\text { et al. } \\
\text { (2001) }\end{array}$ & $\begin{array}{l}\text { Smith } \\
\text { et al. } \\
\text { (2010) }\end{array}$ & $\begin{array}{c}\text { Marks } \\
\& \\
\text { Printy } \\
(2003)\end{array}$ & $\begin{array}{l}\text { Mac- } \\
\text { farlane } \\
(2011)\end{array}$ \\
\hline $\begin{array}{c}\text { Intellectual } \\
\text { potential }\end{array}$ & $\mathbf{X}$ & $\mathbf{X}$ & $\mathbf{X}$ & $\mathbf{X}$ & $\mathbf{X}$ & $\mathbf{X}$ & & & $\mathbf{X}$ \\
\hline $\begin{array}{c}\text { Organiza- } \\
\text { tional } \\
\text { development }\end{array}$ & $\mathbf{X}$ & $\mathbf{X}$ & $\mathbf{X}$ & & $\mathbf{X}$ & & & $\mathbf{X}$ & $\mathbf{X}$ \\
\hline $\begin{array}{l}\text { Core compe- } \\
\text { tencies }\end{array}$ & & $\mathbf{X}$ & $\mathbf{X}$ & & & & $\mathbf{X}$ & & \\
\hline $\begin{array}{l}\text { Intellectual } \\
\text { capital }\end{array}$ & $\mathbf{X}$ & $\mathbf{X}$ & & $\mathbf{X}$ & $\mathbf{X}$ & & $\mathbf{X}$ & & $\mathbf{X}$ \\
\hline Leadership & & & & & & & & $\mathbf{X}$ & $\mathbf{X}$ \\
\hline $\begin{array}{l}\text { Organiza- } \\
\text { tional } \\
\text { management }\end{array}$ & $\mathbf{X}$ & $\mathbf{X}$ & $\mathbf{X}$ & & $\mathbf{X}$ & & $\mathbf{X}$ & & \\
\hline Education & $\mathbf{X}$ & & & & & & & $\mathbf{X}$ & $\mathbf{X}$ \\
\hline $\begin{array}{l}\text { Emotional } \\
\text { intelligence }\end{array}$ & & & & $\mathbf{x}$ & & & & & \\
\hline
\end{tabular}

\section{Defining Attributes}

Walker and Avant (2005) identify defining attributes as characteristics and attributes of a concept that are most frequently associated with the concept and helps to differentiate the concept from other similar concepts. Defining attributes of intellectual leadership in higher education are presented as roles, fuctions and processess.

Roles. Roles of 'intellectual leadership' in higher education is identified in Macfarlane's theory where he defined intellectual leadership in accordance to professors' role in university (2012). Here he identified four roles of intellectual leader - Knowledge producer, Academic Citizen, Boundary transgressor and Public intellectual. Primary orientation of knowledge producer is encouraged through doctorate studies and the supervisor's influence. Academics as knowledge producers seek to deepen lines of conceptual and empirical enquiry and to preserve the norms and values of the discipline. Role of academic citizen enables academics to link their professionl expertise with the needs of and benefit to society, without seeking material advantage. This condition is not rejected, but can not become a primal motivation. It is important not to confuse academic citizen role with knowledge entrepreneurship, who exploit their 
professional knowledge for commercial gain. Boundary transgression for academic means renewal and evolution of his discipline through interdisciplinarity. It is more than combining the perspectives of several disciplines, it involves generating new ideas, approaches and academic territories in relation to emerging problems or issues of the society. Public intellectuals in this case, has to reconcile with their roles - to maintain the loyalty to the ideas of their institutions, and a sense of responsibility to the society.

Functions. Functions of intellectual leader in higher education unfolds also through relevant functions, that in this case are considered as supervision, masterliness and generation of new ideas. Supervision as a role of academic in higher education is relevant in today's reserch (Yaman, 2013; Wright et al., 2012) as they are presented to be acting in different roles in the process of students learning as teaching them reflection-on-action, guiding them, being leaders, negotiators and troubleshooters. Although masterliness is still rarely met in literature and eduction research, it is relevant intellectual leadership function. Masterliness in education has been shown to be a state of advanced professional critical thinking linked to action and informed by research and evidence. An acdemic can only acquire masterliness through the professional freedom afforded by teacher autonomy within empowering frameworks of professional development (Velle, 2013). Professional freedom also leads to a generation of new ideas, as a function of intelectual leader. According to Macfarlane (2012) being allowed a space to have new ideas, experiment and take intellectual risks is a licence for an intellectual leader to benefit society and to raise the role of university.

Process. The processess that intellectual leaders copes with in their activites are maintainance of loyalty to their institution, and responsibility to society. These processess can be disscussed in the light of Bourdieu's ideas of academic capital. According to Mendoza, Kuntz and Berger (2012) the cultural capital associated with the prestige of elite university membership, when combined with the social capital of belonging to a network of recognized scientists, can be converted into better chances of winning federal grants and attracting top tier faculty and students. According to the researchers, for Bourdieu, higher education institutions have a central role in society where the professorate serves as a "state nobility" in the field of academic power and the guardians of much of the nation's symbolic capital.

\section{Antecedents}

Walker and Avant (2005) stated that antecedents are events or incidents that must occur prior to the occurrence of the concept and are factors that precede or cause the concept.

Academic achievement. According to Guay, Marsh and Boivin (2003) and their theories on education psychology, skill-development model implies that 
academic self-concept is a consequence of academic achievement. At this point there can be said that prior academic achievement has an effect on academics self-awareness as an intellectual and also as a leader.

Concern for others. Becoming an intellectual leader also requires to follow the principles of selfless behavior, to think about the needs of others, to reflect the results of other people's behavior and take the time to others, helping them to develop their intellectual potential (Dubrin, 2012).

Intellect. As before mentioned, dictionaries (Chambers, WordWeb) defines intellectual as someone who has a highly developed intellect, great mental ability, and who uses their mind creatively. Therefore, in this case, the antecedent to become intellectual leader is to have a strong knowledge in the discipline field and the ability to use existing competencies wider activities.

\section{Consquences}

Managerial approach to a leadership in higher education "pushes" the academic staff in narrowly perceived entrepreneurial roles in which academic personell usually feel isolated or marginalized as leaders. Therefore, leadership in university has to be informal and distributed for representatives of academic staff to participate fully as intellectual leaders. In today's university researchers are forced to create links between higher education institutions and the economy, however, this situation is an opposition to the traditional role of the Academy. To avoid this twisted attitude towards university, they have to focus their efforts on building a creative, critical and intellectual institution and to invest in the production of symbolic capital which helps to maintain the prestige and rankings. In this way, intellectual leaders, being masters in their field, producing knowledge, maintaining loyalty to their institutions and society and etc. creates a positive change in the University's fundamental educational mission.

\section{Conclusions}

Intellectual leadership concept in the literature is relatively rarely encountered, although the relevance of use of this concept in education field is growing. Higher education in today's environment is facing increasing challenges and roles of academic staff in this case, are gaining importance. Intellectual leadership has greater advantage over the managerial leadership forms in higher education institutions, because this institution grows not only individuals' intellectual potential but also the country's intellectual and symbolic capital. From the review of the literature it is obvious that there is a narrow interest in investigating this concept. Therefore exploring the concept of the intelectual leadership will provide a basis for future theory, research, and practice. 


\section{References}

1. Aarons, G. A. (2006) Transformational and transactional leadership: Association with attitudes toward evidence-based practice. Psychiatric services (Washington, DC) 57 (8), 1162-1169.

2. Barling, J., Slater, F., \& Kelloway, E. K. (2000). Transformational leadership and emotional intelligence: an exploratory study. Leadership \& Organization Development Journal, 21(3), 157-161.

3. Bass, B. M., \& Bass, R. (2009). The Bass handbook of leadership: Theory, research, and managerial applications. SimonandSchuster. com.

4. Bennis, W. (1999). The leadership advantage. Leader to leader, 12, 18-23

5. Bollen, L., Vergauwen, P., \& Schnieders, S. (2005). Linking intellectual capital and intellectual property to company performance. Management Decision, 43(9), 1161-1185

6. Bousquet, M., \& Nelson, C. (2008). How the university works: Higher education and the low-wage nation. NYU Press.

7. Burns, J. M. (1978). Leadership. New York: Harper \& Row.

8. Dealtry, R. (2001). Managing intellectual leadership in corporate value. Journal of Workplace Learning, 13(3), 119-124.

9. Drew, G. (2010). Issues and challenges in higher education leadership: Engaging for change. The Australian Educational Researcher, 37(3), 57-76.

10. DuBrin, A. J. (2012). Leadership: Research Findings, Practice, and Skills: Research Findings, Practice, and Skills. Cengage Learning.

11. Freeman Jr, S., \& Kochan, F. K. (2013). University presidents' perspectives of the knowledge and competencies needed in 21 st century higher education leadership. Journal of Educational Leadership in Action, 1(1), 1-2.

12. Graham, G. (2005). The institution of intellectual values: Realism and idealism in higher education (Vol. 5). Imprint Academic.

13. Guay, F., Marsh, H. W., \& Boivin, M. (2003). Academic self-concept and academic achievement: Developmental perspectives on their causal ordering. Journal of Educational Psychology, 95(1), 124.

14. Macfarlane, B. (2012). Intellectual Leadership in Higher Education: Renewing the Role of the University Professor. Research into Higher Education. Routledge, Taylor \& Francis Group.

15. Macfarlane, B. (2011). Professors as intellectual leaders: Formation, identity and role. Studies in Higher Education, 36(1), 57-73.

16. Marks, H. M., \& Printy, S. M.(2003). Principal leadership and school performance: An integration of transformational and instructional leadership. Educational administration quarterly, 39(3), 370-397.

17. Mendoza, P., Kuntz, A. M., \& Berger, J. B. (2012). Bourdieu and academic capitalism: Faculty" Habitus" in materials science and engineering. The Journal of Higher Education, 83(4), 558-581.

18. Northouse, P. (2004). Leadership: Theory and practice (3rd ed.). Thousand Oaks, CA: Sage.

19. Prahalad, C. K. (1993). The role of core competencies in the corporation. Research Technology Management, 36, 40-40.

20. Roos, G., Bainbridge, A., \& Jacobsen, K. (2001). Intellectual capital analysis as a strategic tool. Strategy \& Leadership, 29(4), 21-26.

21. Said, E. (1994). Representations ofthe intellectual. New York: Pantheon.

22. Shaw, K. (2012). Leadership through instructional design in higher education. Online Journal of Distance Learning Administration, 15(3). 
23. Smith, D. D., Robb, S. M., West, J., \& Tyler, N. C. (2010). The changing education landscape: How special education leadership preparation can make a difference for teachers and their students with disabilities. Teacher Education and Special Education: The Journal of the Teacher Education Division of the Council for Exceptional Children, 33(1), 25-43.

24. Velle, L. L. (2013). Masterliness in the teaching profession: global issues and local developments. Journal of Education for Teaching, 39(1), 2-8.

25. Walker, L. O., \& Avant, K. C. (2005). Strategies for theory construction in nursing. (4th ed.).Upper Saddle River, NJ: Pearson Prentice Hall.

26. Wepner, S. B., D'Onofrio, A., Wilhite, S. C. (2008). The leadership dimensions of education deans. Journal of Teacher Education, 59(2), 153-169.

27. Wright, S. C., Grenier, M., \& Channell, K. (2012). University Supervision within Physical Education Teacher Education. Education, 132(4).

28. Yaman, S. (2013.) Supervision and the roles of supervisors within the context of preservice teacher education in Turkey. International Journal of Academic Research, 5(5), 227-232.

Specialist of the Center for Quality and Innovations

\section{Agnè Sūnelaitytė}

Head of the Center for Quality and Innovations

Prof. (hp) dr.
Vytautas Magnus University, Kaunas, Lithuania Email.: a.sunelaityte@kic.vdu.lt

Vytautas Magnus University, Kaunas, Lithuania Email.: v.zydziunaite@kic.vdu.lt 